\title{
Protective Effects of Imatinib and Ginkgo Biloba on Cisplatin- induced Ovarian Damage in Rats
}

\author{
İmatinib ve Ginkgo Bilobanın Sıçanlarda Sisplatin Kaynaklı Over Hasarı Üzerine \\ Koruyucu Etkilerinin İncelenmesi
}

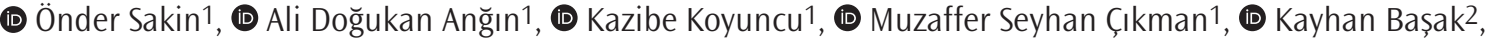 \\ (D) Asuman Orçun Kaptanağası 3
}

${ }^{1}$ Istanbul Kartal Dr. Lütfi Kırdar City Hospital, Clinic of Obstetrics and Gynecology, İstanbul, Turkey

2istanbul Kartal Dr. Lütfi Kırdar City Hospital, Clinic of Pathology, i̇stanbul, Turkey

3istanbul Kartal Dr. Lütfi Kırdar City Hospital, Clinic of Biochemistry, İstanbul, Turkey

\begin{abstract}
Introduction: In our study we aimed to observe the protective effects of imatinib and ginkgo biloba (GB) on cisplatin (CP)induced ovarian damage in rats.

Methods: Thirty-two female rats were included and assigned to four groups. Group 1 had no medication. Their ovaries were removed for examination and the serum Anti-Mullerian hormone (AMH) levels were measured. Group 2 received a single dose of $7.5 \mathrm{mg} / \mathrm{kg}$ intramuscular CP. Group 3 received a single dose of $7.5 \mathrm{mg} / \mathrm{kg}$ oral imatinib and 30 minutes later, a single dose of $7.5 \mathrm{mg} / \mathrm{kg}$ intramuscular CP was administered. Group 4 received $80 \mathrm{mg} / \mathrm{kg}$ oral GB for 10 days. Sixty minutes after the first administration of the GB, a single dose of 7.5 $\mathrm{mg} / \mathrm{kg}$ intramuscular CP was administered. The ovaries and serum AMH levels of the rats were assessed after 10 days of observation.
\end{abstract}

Results: Comparing group 1 and 2 showed that the total histopathological ovarian damage scores increased in the latter $(p=0.044)$. This group also had decreased primordial follicles, preantral follicles and serum AMH $(p=0.001, p=0.004$ and $p<0.001$ respectively). In group 3 , total histopathological ovarian damage score increased $(p=0.020)$, and a reduction in primordial follicles $(p=0.008)$ and serum AMH levels $(p<0.001)$ was observed. In group 4 , total histopathological ovarian damage score increased $(p=0.016)$ as in groups 2 and 3. There was also a reduction in primordial follicles, preantral follicles and serum AMH levels $(p<0.00, p=0.010$ and $p<0.001$ respectively).

Conclusion: It was concluded that imatinib and GB were not effective in preventing CP-induced ovarian damage in rats.

Keywords: Cisplatin, imatinib, ginkgo biloba, Anti-Mullerian hormone, ovary, rat

\section{öz}

Amaç: Çalışmamızda, imatinib ve ginkgo bilobanın (GB) sıçanlarda sisplatin (CP) kaynaklı over hasarı üzerindeki koruyucu etkilerini gözlemlemeyi amaçladık.

Yöntemler: Çalıșmamıza toplam 32 erişkin diși rat alındı ve 4 gruba ayrıldı. illk gruba ilaç verilmedi. Muayene için sıçanların overleri çıkarıldı ve serum Anti-Mullerian hormon (AMH) seviyeleri ölçüldü. Grup 2'ye tek doz 7,5 mg/kg intramüsküler $\mathrm{CP}$ verildi. On günlük gözlemden sonra, overler ve sıçanların serum AMH seviyeleri değerlendirildi. Grup 3'e tek doz 7,5 mg/ $\mathrm{kg}$ oral imatinib verildi ve 30 dakika sonra, tek doz 7,5 mg/kg intramüsküler CP uygulandı. Grup 4 on gün boyunca 80 mg/kg oral GB aldı. GB ilk uygulamasından 60 dakika sonra, tek bir doz 7,5 mg/kg intramüsküler CP uygulanmıştır. Gruplar ve grup 4'ün overleri ve serum AMH düzeyleri, 10 günlük gözlemden sonra değerlendirildi.

Bulgular: Grup 2'de total histopatolojik over hasarı skoru grup 1'e göre arttı $(p=0,044)$. Ayrıca grup 2'de primordiyal foliküller, preantral foliküller ve serum AMH düzeyleri azaldı (sırasıyla, $p=0,001, p=0,004$ ve $p<0,001)$, 3. grupta, aynı zamanda toplam histopatolojik over hasarı skoru $(p=0,020)$ arttı. Primordiyal foliküllerde $(p=0,008)$ ve serum AMH düzeylerinde azalma gözlendi $(p<0,001)$. Grup 4'te toplam histopatolojik over hasarı skoru grup 2 ve grup 3'te olduğu gibi arttı $(p=0,016)$. Ayrıca primordiyal foliküllerde, preantral foliküllerde ve serum $\mathrm{AMH}$ düzeylerinde azalma olduğu gözlendi $(p<0,00, p=0,010$ ve sırasıyla $p<0,001)$.

Sonuç: İmatinib ve GB'nin sıçanlarda CP'nin neden olduğu yumurtalık hasarını önlemede etkili olmadığı sonucuna varıldı.

Anahtar Kelimeler: Sisplatin, imatinib, ginkgo biloba, AntiMullerian hormon, over, siçan

Cite this article as/Atıf: Sakin Ö, Anğın AD, Koyuncu K, Çıkman MS, Başak K, Orçun Kaptanağası A. Protective Effects of Imatinib and Ginkgo Biloba on Cisplatin-induced Ovarian Damage in Rats. İstanbul Med J 2020; 21(4): 281-9.

(C) Copyright 2020 by the University of Health Sciences Turkey, Istanbul Training and Research Hospital/Istanbul Medical Journal published by Galenos Publishing House.

(C) Telif Hakkı 2020 Sağıı Bilimleri Üniversitesi Istanbul Ĕgitim ve Araştırma Hastanesi/Istanbul Tıp Dergisi, Galenos Yayınevi tarafından basılmıștır. 


\section{Introduction}

Cisplatin (CP) is one of the first chemotherapy drugs in cancer treatment. CP is also known as "the penicillin of cancer" as it is a widely used chemotherapeutic agent in the medical management of cancers worldwide. CP use in clinical practice has increased day by day after its approval of the Food and Drug Administration for cancer treatment in 1978 (1). Lung, head and neck, ovarian, cervical, bladder and testicular tumours are the most common tumours treated with CP (2). DNA is the main target of CP. CP interferes with DNA synthesis and repair mechanisms, causing DNA damage and subsequently inducing apoptosis in tumours. The damage in DNA synthesis affects especially blood cells, germ cells and young cells (3).

$\mathrm{CP}$ is one of the most effective chemotherapeutic agents especially in childhood cancers and the average cure rate is $85 \%$ in literature $(4,5)$. On the other hand, CP has some disadvantages because it interferes with DNA repair mechanisms. The incidence of secondary tumours mostly in proliferative organs is higher in patients receiving $\mathrm{CP}$, especially at young ages (6). This is one of the limiting features of CP. At this point CP-induced ovarian damage appears to be a very important side effect, especially for women who want to preserve ovarian functions (7). CPinduced ovarian damage may cause deterioration in quality of life and increase in treatment costs, from ovarian failure and infertility (8).

It is also known that CP induces the production of free oxygen radicals, which have cytotoxic effects on normal cells and causes oxidative stress throughout the body $(9,10)$. Some evidence found that antioxidant substances reduce organ damage from oxidative stress caused by CP (1113).

Imatinib is a competitive tyrosine kinase inhibitor (TKI) and generally used in cancer therapy (14). It is a TKI, inhibiting Abelson tyrosine kinase (c-abl), platelet derived growth factor receptor and receptor tyrosine kinase (15). Imatinib can affect all basic cellular functions (cell signalling, proliferation and differentiation), including ovarian follicles $(16,17)$. In literature, it has been proposed as a medication to prevent primordial follicle loss induced by CP, based on its ability to inhibit c-abl kinase inhibitor $(18,19)$. However, further studies are required on imatinib coadministration to prevent ovarian functions in CP treatment (20).

In recent studies, some antioxidant plants have been shown to have preservative effects against chemotherapy-induced reproductive organ damage (21). Ginkgo biloba (GB) has been used in traditional Chinese medicine for 5,000 years. It is a potent antioxidant and directly effective on free oxygen radicals (22). Besides the antioxidant effects of $G B$, its anticancer effects have been discussed in some publications $(23,24)$.

In the current study, we aimed to investigate whether imatinib and GB, have protective effects on CP-induced ovarian damage.

\section{Methods}

This is an experimental animal study. In May 2019, the research was conducted after approval from the animal experiments local ethics committee of the Üsküdar University (no: 2019-05, date: 15.02.2019).

\section{Animals Used in the Research}

In this study, female wistar albino rats of the norvegicus species were used. The weighed from 219 to 265 grams, and were aged between 10 and 12 weeks. Four to five rats were placed in each cage. They received light for 12 hours between $8 \mathrm{am}$ and $8 \mathrm{pm}$. They had unrestricted access to tap water and standard rodent pellet food at an average room temperature of 21 to 23 degrees. Humidity rate was kept between 40 and 50 percent.

\section{Experimental Groups}

Group 1 (the control group): These rats underwent a laparotomy at baseline and the ovaries were removed. Blood was drawn from the inferior vena cava for Anti-Mullerian hormone (AMH) testing.

Group 2 (the CP group): Rats received CP intramuscularly at a dose of $7.5 \mathrm{mg} / \mathrm{kg}$ at baseline (25) and underwent an oophorectomy at the end of day 10 . At least 2-3 $\mathrm{mm}^{3}$ of blood was drawn from the inferior vena cava for AMH testing.

Group 3 (the CP + imatinib group): Thirty minutes after the first dose of imatinib, rats received intramuscular CP at a dose of $7.5 \mathrm{mg} / \mathrm{kg}$. They then received oral imatinib (Glivec ${ }^{\circledR}$, Novartis, İstanbul, Turkey) for 10 days at a dose $7.5 \mathrm{mg} / \mathrm{kg}(18,20)$. Both ovaries were removed surgically at the end of day 10 . At least $2-3 \mathrm{~mm}^{3}$ of blood was drawn from the inferior vena cava for $\mathrm{AMH}$ testing.

Group 4 (the $\mathrm{CP}+\mathrm{GB}$ group): Sixty minutes after the first administration of $\mathrm{GB}$, rats received $\mathrm{CP}$ at a dose of $7.5 \mathrm{mg} / \mathrm{kg}$ intramuscularly. They additionally received GB (Ginkgo biloba leaf extract, Solgar, İstanbul, Turkey) orally, dissolved in distilled water, for 10 days at a dose $80 \mathrm{mg} /$ $\mathrm{kg}$ (26). Both ovaries were removed surgically at the end of day 10 , and at least 2-3 $\mathrm{mm}^{3}$ of blood was drawn from the inferior vena cava for AMH testing.

\section{Cisplatin Dose and Preparation}

CP was administered intramuscularly only at baseline at a dose of 7.5 $\mathrm{mg} / \mathrm{kg}$. While preparing the drug; we used the central drug preparation unit of our hospital (with Robotic Chemotherapy Drug Preparation System) in a closed environment where microbiological contamination and employee exposure risks are eliminated under conditions that comply with national and international standards. These standards included: negative pressure indoor air environment complying with ISO 5, Class 100 and GMP Class A, double HEPA filter air cleaning system, safe waste management system, high capacity laminator current and dose sensitivity information (gravimetric and volumetric) measurement and the barcode system.

\section{Operational Procedures}

Powder free sterile latex gloves were used in all surgical procedures. After rats were decapitated, blood samples were taken for AMH hormone evaluation. Then laparotomy was performed in the supine position and oophorectomy was done. Operations were completed between 5 and 10 minutes to avoid the drying effects of room air (Figure 1). 


\section{Histopathological Examination}

All examinations were performed by the same pathologist blindly. Removed ovaries were put into $10 \%$ formalin. Paraffin blocks were prepared within 24 hours after treatment. Five micrometre tissue sections were sampled and follicle examination in each ovarian tissue was made by taking five different sections. Tissues were stained with haematoxylin eosin and examined by light microscopy (Olympus

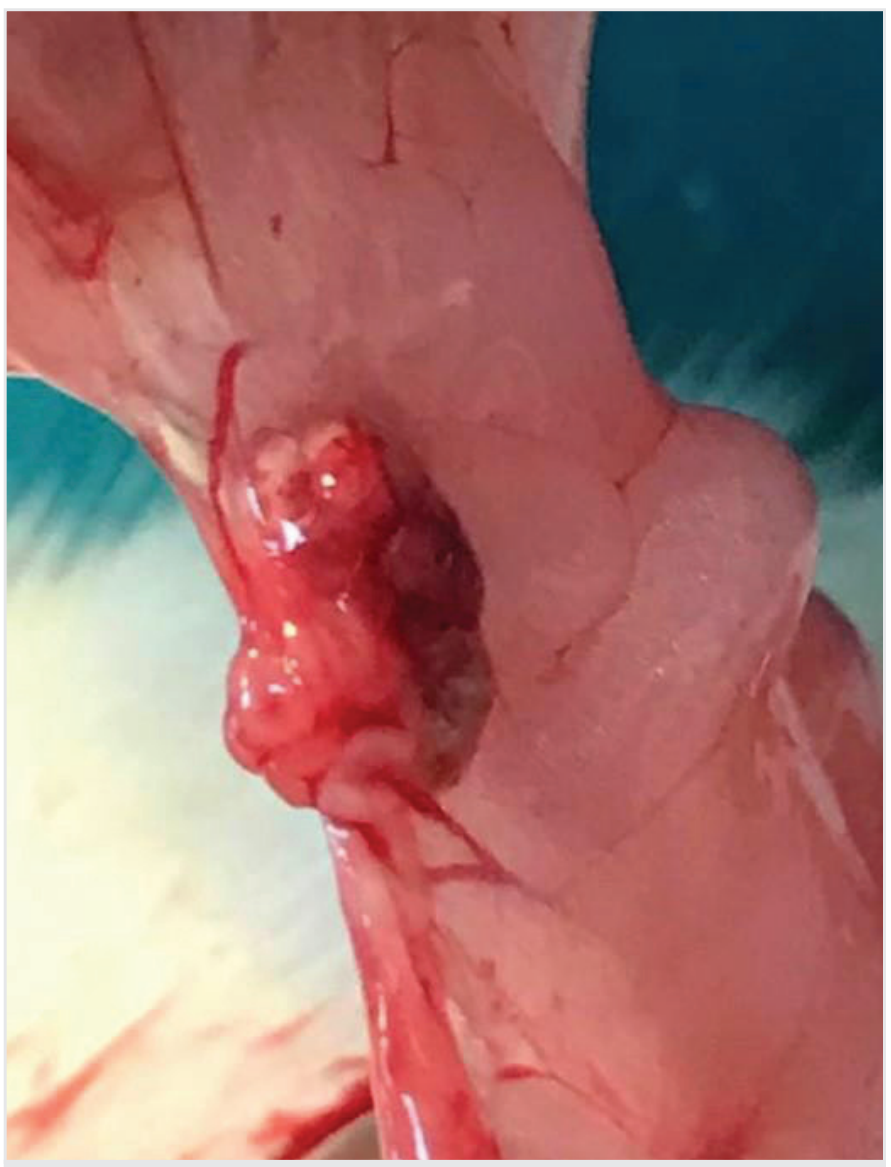

Figure 1. Excision of the ovary

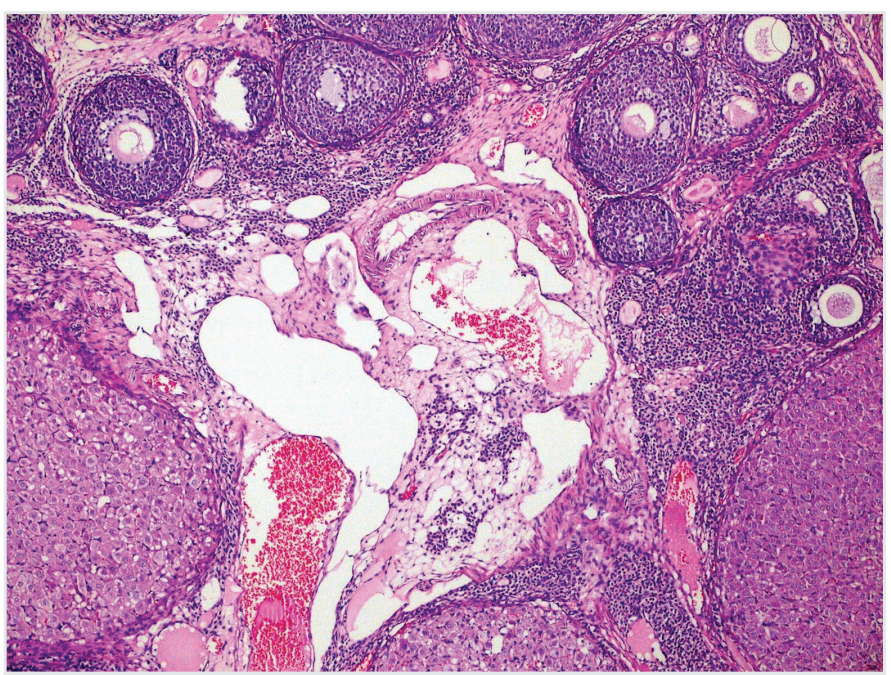

Figure 2. Oedema and vascular congestion x200 haematoxylin eosin
Clinical Microscope, Tokyo, Japan). Paraffin blocks were sectioned using a microtome blade (Leica, Nussloch, Germany).

Histopathological injury scores were evaluated as described by Celik et al. (27). Cellular degeneration, vascular congestion, oedema, haemorrhage and inflammation were examined. The evaluations were graded from 0 to 4 .

Grade 0: No abnormal findings were detected. Grade 1: mild vascular congestion, mild oedema, absence of haemorrhage or leukocyte infiltration. Grade 2: moderate vascular congestion, moderate oedema, absence of haemorrhage or leukocyte infiltration. Grade 3: severe vascular occlusion, severe oedema, minimal leukocyte infiltration and minimal haemorrhage. Grade 4: severe vascular occlusion, severe oedema, leukocyte infiltration and haemorrhage (Figure 2).

To evaluate ovarian reserves, all follicles were examined as described by Parlakgumus et al. (28). Primordial, primary, secondary (preantral), tertiary (antral) and atretic follicles were counted (Figure 3, 4). A primordial follicle was defined as oocyte with epithelial cell layer in

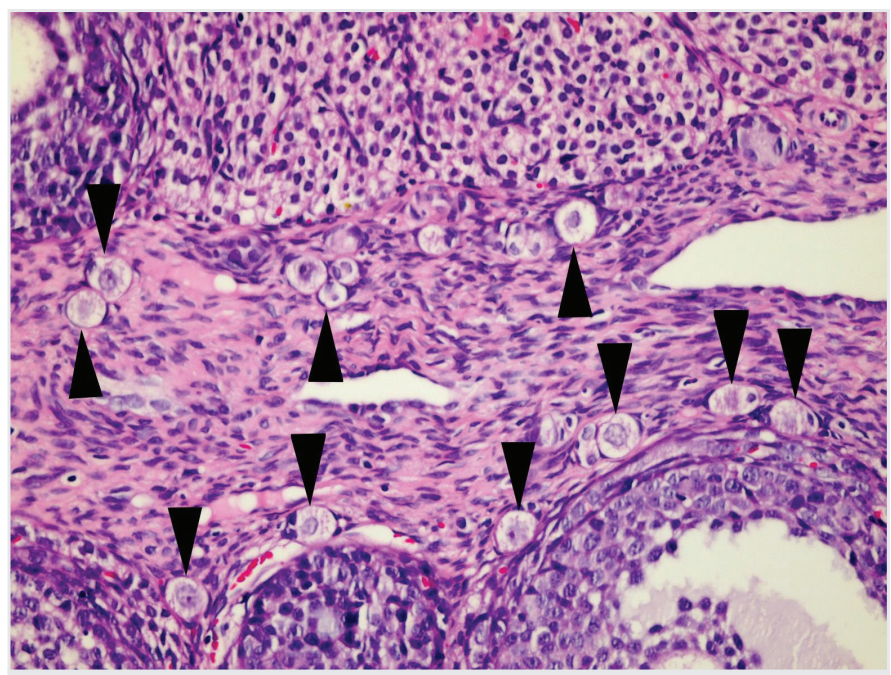

Figure 3. Primordial follicles x400 haematoxylin eosin

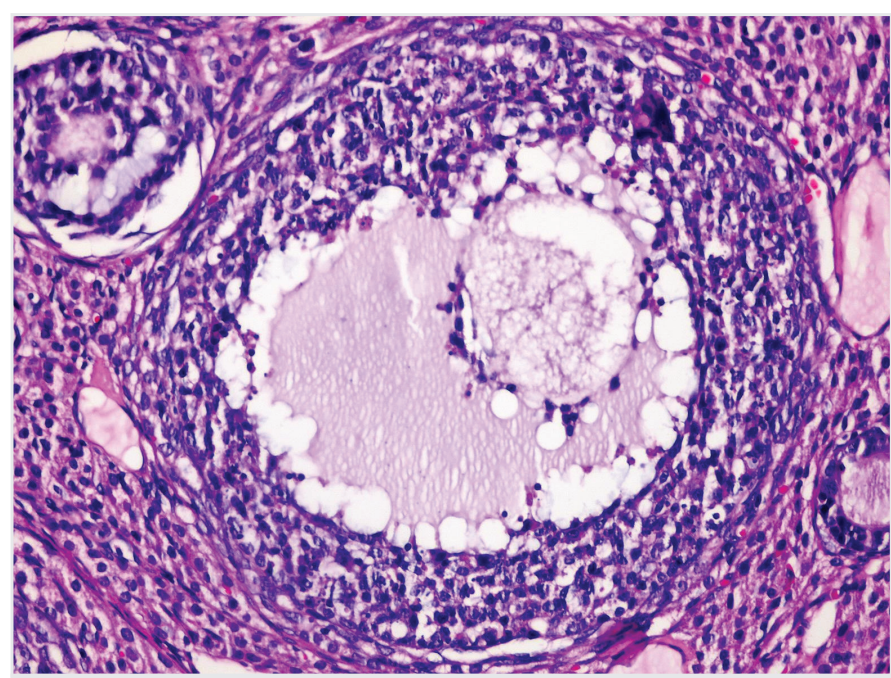

Figure 4. Degenerated follicle x400 haematoxylin eosin 
only one layer. A primary follicle was defined as a follicle surrounded by one or more layers of cuboidal granulosa cells. A secondary (preantral) follicle was defined as a follicle consisting of antrum folliculi and zona pellucida surrounded by two or more cell layers. Tertiary follicles were defined as follicles with layers of antrum, stratum granulosum and surrounding cumulus oophorus. For the atretic follicle, the basement membrane that separated the oocyte from granulosa cells was often thickened to become the glassy membrane. Fibrous material replaced the granulosa cells and loss of cohesion could also be observed in granulosa cells.

\section{Anti-Mullerian Hormone Assays}

Blood samples were collected into tubes containing lithium heparin (BD Vacutainer Plasma tubes, Manchester, England). The concentration of the Lithium Heparin additive in these tubes was 17 international units of heparin/mL of blood. Blood samples were centrifuged within 30 minutes of sampling. After 15 minutes of centrifugation at 1000xg, serum was removed and remaining plasma was transferred into an eppendorf tube and stored frozen at $-20{ }^{\circ} \mathrm{C}$ until the time of analysis $\mathrm{AMH}$ concentrations were measured in " $\mathrm{ng} / \mathrm{mL}$ " of plasma using the enzyme-linked immunosorbent assay method. The rat AMH kit used in study had a sensitivity of $0.10 \mathrm{~g} / \mathrm{mL}$, a detection range of 0.16 to $10 \mathrm{ng} /$ $\mathrm{mL}$ and a coefficient of variation less than $10 \%$ (Elabscience ${ }^{\circledR}$, Rat AMH kit; Houston, Texas, ABD). The laboratory technician of the university hospital laboratory was blinded to the study groups All samples were analysed in the same assay.

\section{Statistical Analysis}

All the data were analysed by SPSS 25.0 (SPSS Inc., Chicago, IL, USA). Results were presented as number, percentage, average and standard deviation. One-way ANOVA, Kruskal-Wallis and Tamhane post hoc tests were used for comparison between the groups. The correlations between $\mathrm{AMH}$ and other variables were investigated by Spearman correlation analysis. Statistical significance level was accepted as $p<0.05$.

\section{Results}

There were no significant differences between the study groups concerning rat weights (ANOVA $\mathrm{F}=0.410 ; \mathrm{p}=0.747$ ) (minimum 219 grams, maximum 265 grams). Histopathological features of the groups were compared and shown in Table 1 . The control group showed no increase in ovarian damage scores. Tamhane post hoc analysis revealed significant subgroup differences concerning oedema between the control and $C P$ groups $(p=0.032)$, concerning vascular congestion between control and both $C P(p=0.023)$ and $C P+G B$ groups $(p=0.007)$. Also, the total damage score was significantly different between the control group and CP ( $p=0.044), C P+$ imatinib $(p=0.020)$, as well as CP + GB groups ( $p=0.016)$. Tamhane post hoc comparisons are given in Table 2. Group 1 with normal ovaries (score: 0.13 ) had the lowest ovarian damage scores and group 2 with only CP had the highest scores (score: 3.47). In the follicle count, most follicles were seen in the control group (group 1), while the least follicles was seen in CP + GB group (group 4).

Follicle counts in the study groups were compared and is shown in Table 3. Tamhane post hoc analysis revealed significant subgroup differences in the number of primordial follicles between the control and $C P+$ imatinib $(p=0.008)$, CP alone $(p=0.001)$, as well as $C P+G B$ groups $(p<0.001)$. There were significant differences in the number of secondary follicles between the control group and both CP $(p=0.004)$ as well as CP + GB groups $(p=0.010)$.

A significant correlation between AMH levels and over volume in the control group (Table 4). Also, positive correlations were detected between the total damage score and the number of atretic follicles in the $\mathrm{CP}$ group.

The mean AMH level was highest in the control group $(2.73 \mathrm{ng} / \mathrm{mL})$, and lowest in $\mathrm{CP}+\mathrm{GB}$ group $(0.11 \mathrm{ng} / \mathrm{mL})$. AMH values were significantly lower in all groups compared to control rats ( $p<0.001$ in all). A significant correlation between AMH levels and over volume in the control group (group 1). Also, positive correlations were detected between the total damage score and the number of atretic follicles in the CP group (group 3) (Table 5).

\section{Discussion}

Some chemotherapeutics used for cancer treatment are major causes of ovarian damage. Prevention of primordial follicle destruction and premature ovarian ageing will be beneficial for children, adolescents and young women with fertility desire. Primordial follicles are very sensitive to radiotherapy and chemotherapy. Follicular reserve decreases and premature ageing occurs (18), especially during chemotherapy. Both in vitro and in vivo studies have shown that $\mathrm{CP}$ administration clearly causes increased free oxygen radicals $(9,10)$. In animals treated with $C P$,

Table 1. Comparison of histopathological damage scores of control vs Cisplatin, Cisplatin + Imatinib and Cisplatin + Ginkgo biloba groups

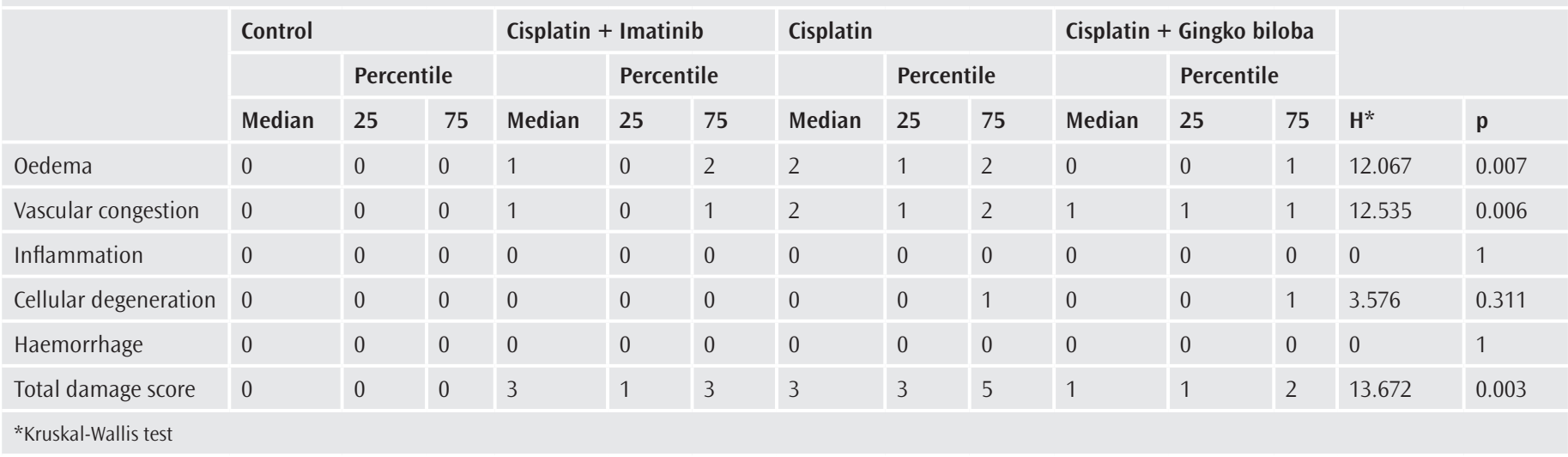


free oxygen radicals cause multiple cellular changes and organ damage. Data from animal studies indicate that if oxidative stress is blocked, organs will be preserved $(9,11)$.

In another study, imatinib was found to be effective in preventing primordial oocyte damage caused by $\mathrm{CP}$ or other c-abl inhibitors.
Because of this, it was suggested that imatinib administration with chemotherapeutics might be considerable (5).

Imatinib acts by inhibiting c-abl, a TKI. Thus, imatinib has been shown to cause the accumulation of p63, which is an oocyte-specific homologue of p53 and activates apoptosis in DNA damage $(18,29,30)$. Imatinib affects

Table 2. Post-hoc bi-variate comparison of the variables using the Tamhane's test

\begin{tabular}{|c|c|c|c|c|c|c|}
\hline & & & & & 95\% Confiden & Interval \\
\hline Dependent Variable & (I) Group & (J) Group & $\begin{array}{l}\text { Mean Difference } \\
(\mathrm{I}-\mathrm{J})\end{array}$ & $\mathbf{p}$ & Lower Bound & $\begin{array}{l}\text { Upper } \\
\text { Bound }\end{array}$ \\
\hline Oedema & Cisplatin + Imatinib & Cisplatin & -0.455 & 0.942 & -1.99 & 1.08 \\
\hline & & Cisplatin + Gingko biloba & 0.657 & 0.501 & -0.55 & 1.87 \\
\hline & & Control & 1.035 & 0.096 & -0.16 & 2.23 \\
\hline & Cisplatin & Cisplatin + Gingko biloba & 1.112 & 0.132 & -0.24 & 2.47 \\
\hline & & Control & 1.490 & 0.032 & 0.13 & 2.85 \\
\hline & Cisplatin + Gingko biloba & Control & 0.378 & 0.377 & -0.28 & 1.03 \\
\hline Vascular congestion & Cisplatin + Imatinib & Cisplatin & -0.477 & 0.875 & -1.81 & 0.86 \\
\hline & & Cisplatin + Gingko biloba & -0.095 & 1.000 & -1.19 & 1.00 \\
\hline & & Control & 0.892 & 0.108 & -0.17 & 1.96 \\
\hline & Cisplatin & Cisplatin + Gingko biloba & 0.381 & 0.909 & -0.81 & 1.57 \\
\hline & Control & Control & 1.369 & 0.023 & 0.20 & 2.54 \\
\hline & Cisplatin + Gingko biloba & Control & 0.988 & 0.007 & 0.31 & 1.67 \\
\hline Cellular degeneration & Cisplatin + Imatinib & Cisplatin & -0.367 & 0.912 & -1.54 & 0.80 \\
\hline & & Cisplatin + Gingko biloba & -0.137 & 0.999 & -1.11 & 0.84 \\
\hline & & Control & 0.244 & 0.695 & -0.35 & 0.84 \\
\hline & Cisplatin & Cisplatin + Gingko biloba & 0.230 & 0.995 & -1.05 & 1.51 \\
\hline & & Control & 0.611 & 0.470 & -0.56 & 1.78 \\
\hline & Cisplatin + Gingko biloba & Control & 0.380 & 0.720 & -0.57 & 1.33 \\
\hline Total damage score & Cisplatin + Imatinib & Cisplatin & -1.298 & 0.790 & -4.57 & 1.98 \\
\hline & & Cisplatin + Gingko biloba & 0.425 & 0.983 & -1.43 & 2.28 \\
\hline & & Control & 2.038 & 0.020 & 0.33 & 3.75 \\
\hline & Cisplatin & Cisplatin + Gingko biloba & 1.723 & 0.499 & -1.51 & 4.95 \\
\hline & & Control & 3.336 & 0.044 & 0.09 & 6.58 \\
\hline & Cisplatin + Gingko biloba & Control & 1.613 & 0.016 & 0.30 & 2.93 \\
\hline
\end{tabular}

Table 3. Comparison of ovarian follicle counts and Anti-Mullerian hormone levels between groups

\begin{tabular}{|c|c|c|c|c|c|c|c|c|c|c|c|c|c|c|}
\hline & \multicolumn{3}{|l|}{ Control } & \multicolumn{3}{|c|}{ Cisplatin + Imatinib } & \multicolumn{3}{|l|}{ Cisplatin } & \multicolumn{3}{|c|}{ Cisplatin + Gingko biloba } & \multirow[b]{3}{*}{$H^{*}$} & \multirow[b]{3}{*}{$p$} \\
\hline & \multirow[b]{2}{*}{ Median } & \multicolumn{2}{|c|}{ Percentile } & \multirow[b]{2}{*}{ Median } & \multicolumn{2}{|c|}{ Percentile } & \multirow[b]{2}{*}{ Median } & \multicolumn{2}{|c|}{ Percentile } & \multirow[b]{2}{*}{ Median } & \multicolumn{2}{|c|}{ Percentile } & & \\
\hline & & 25 & 75 & & 25 & 75 & & 25 & 75 & & 25 & 75 & & \\
\hline $\begin{array}{l}\text { Number of } \\
\text { primordial follicles }\end{array}$ & 12.00 & 11.00 & 14.00 & 5.00 & 3.00 & 8.00 & 4.00 & 3.00 & 9.00 & 4.00 & 3.00 & 6.00 & 16.753 & 0.001 \\
\hline $\begin{array}{l}\text { Number of } \\
\text { primary follicles }\end{array}$ & 13.00 & 10.00 & 14.00 & 11.00 & 7.00 & 13.00 & 8.00 & 8.00 & 11.00 & 7.00 & 6.00 & 9.00 & 8.659 & 0.034 \\
\hline $\begin{array}{l}\text { Number of } \\
\text { secondary follicles }\end{array}$ & 10.00 & 8.00 & 10.00 & 7.00 & 5.00 & 8.00 & 5.00 & 5.00 & 8.00 & 5.00 & 3.00 & 8.00 & 13.164 & 0.004 \\
\hline $\begin{array}{l}\text { Number of tertiary } \\
\text { follicles }\end{array}$ & 8.00 & 7.00 & 10.00 & 6.00 & 6.00 & 7.00 & 8.00 & 7.00 & 10.00 & 9.00 & 7.00 & 10.00 & 4.94 & 0.176 \\
\hline $\begin{array}{l}\text { Number of atretic } \\
\text { follicles }\end{array}$ & 0.00 & 0.00 & 1.00 & 0.00 & 0.00 & 0.00 & 0.00 & 0.00 & 1.00 & 1.00 & 0.00 & 2.00 & 3.047 & 0.384 \\
\hline
\end{tabular}


early folliculogenesis in the postnatal period and decreases activation of primordial follicle pool in rat ovaries, causing an increase in the expression of AMH proteins (31). Another recent study showed a novel finding that CP-induced damage is associated with increased expression of TAp63 phosphorylated at Ser395 and Ser160/162 residues in human ovary. So, imatinib use could not provide protection for human ovarian cells. Besides, it was stated that imatinib itself may be a gonadotoxic agent for ovarian follicles (32). However, further studies are needed to investigate the long-term outcomes and their effects on fertility.

\section{Conclusion}

It is not possible to clearly describe the success of imatinib in reducing ovarian damage induced by CP. In our study, total damage score increased with the use of both CP and imatinib (group 3) compared to

Table 4. Correlations between Anti-Mullerian hormone levels and variables

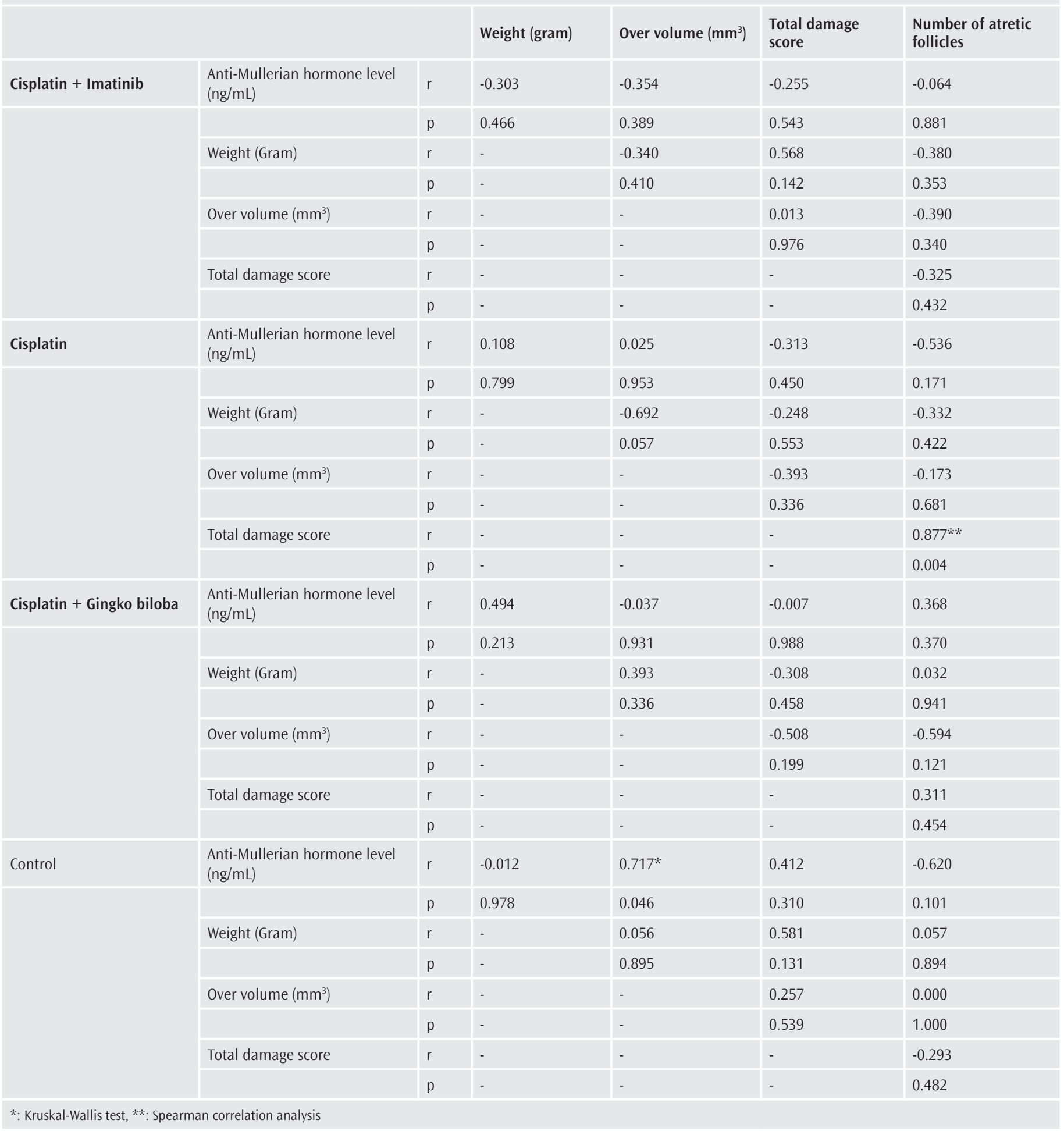


control ovaries (group 1) $(p=0.020)$, and the number of primary follicles in group 3 decreased compared to group $1(p=0.008)$. Also, the mean AMH level $(0.19 \mathrm{ng} / \mathrm{mL})$ significantly decreased $(p<0.001)$.

GB has been shown to be an antioxidant with protective effects on CPinduced cellular damage. In a study by Chang et al. (33), the effect of GB on total ovarian follicle count, apoptotic indices and cytoplasmic protein levels were examined and its protective effects on ovarian reserve have been showed.
On the other hand, it was reported that GB inhibits growth in ovarian cancer cells and triggers apoptosis. It has been stated that GB combination with chemotherapeutics could provide a preventive strategy for infertility $(21,34,35)$. CP and protective agents against CP-induced organ damages are current issues in cancer treatment in patients of reproductive age, but none of the studies in literature have examined the effect of $\mathrm{CP}$ treatment on ovarian damage scores, AMH levels, ovarian, preantral, antral and atretic follicles. In our study, vascular congestion $(p=0.007)$ and total damage score $(p=0.016)$ were increased compared to control

Table 5. Correlations between rat weights, over volume, total damage score, number of atretic follicles, and Anti-Mullerian hormone levels

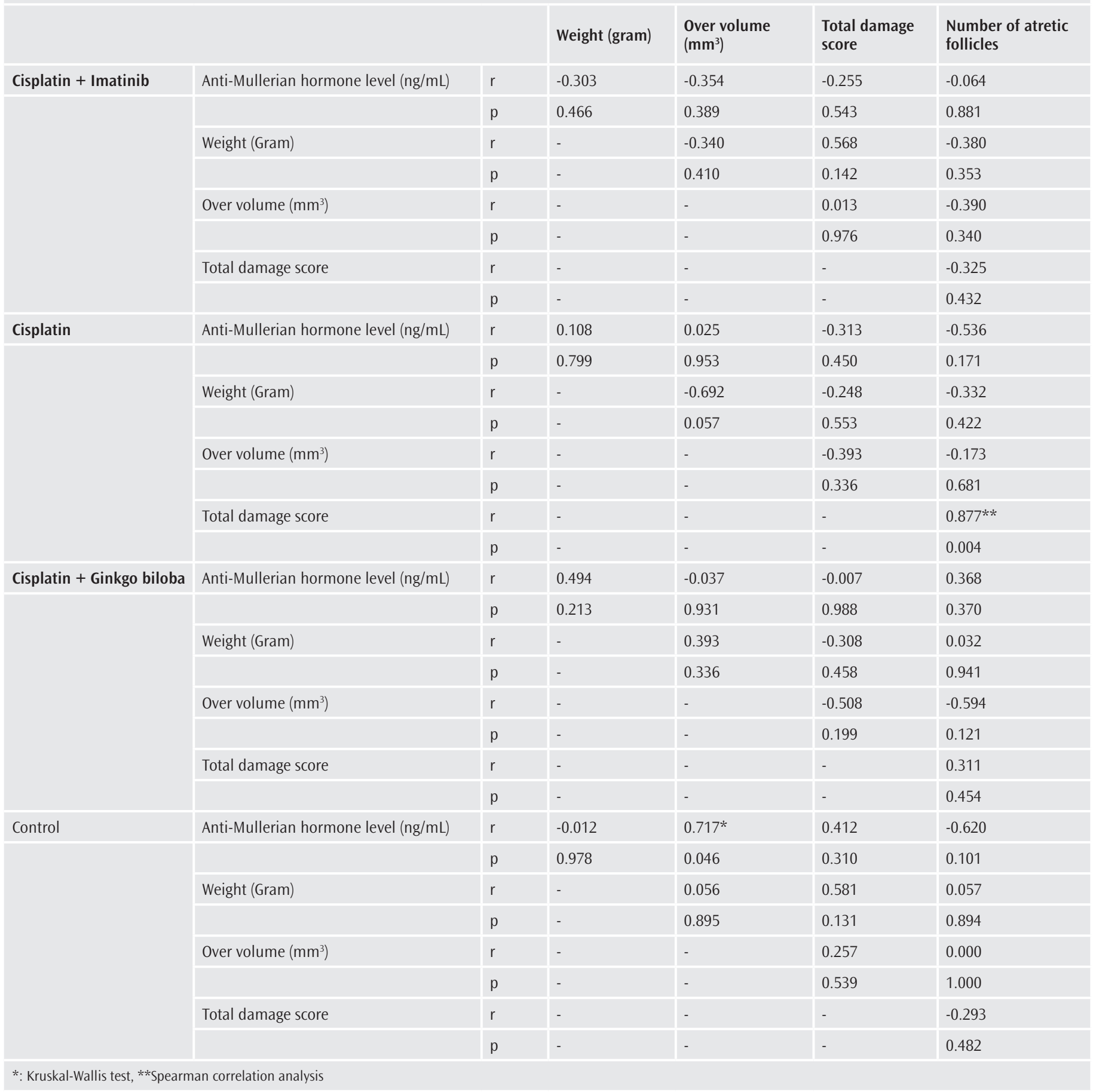


ovaries after the use of $\mathrm{CP}$ in combination with $\mathrm{GB}$. The mean number of ovarian follicles was the least in the $\mathrm{CP}+\mathrm{GB}$ group. Both primary $(p<0.001)$ and preantral follicles $(p=0.01)$ decreased and $A M H$ levels were also significantly lower in the $C P+G B$ group $(p<0.001)$.

It is important how all the apoptotic indices, cytoplasmic protein levels, antioxidant mechanisms, enzymatic changes, histopathological damage scores, follicular examinations and ovarian reserve tests help us in cancer treatment in young patients of reproductive ages. And more importantly, these parameters have real clinical implications for reproductive organs and fertility. We investigated whether follicle count and AMH levels, which are the two most used parameters in the evaluation of fertility in the clinic, can be maintained with imatinib and $\mathrm{GB}$ in CP-treated rats.

In our study, we concluded that imatinib and GB were not effective in preventing CP-induced ovarian damage.

\section{Ethics}

Ethics Committee Approval: The study was conducted after approval from the animal experiments local ethics committee of the Üsküdar University (no: 2019-05, date: 15.02.2019). This study was conducted at the Animal Testing Laboratory of the University after the approval of the Ethics Committee.

Informed Consent: Experimental animal study.

Peer-review: Externally peer-reviewed

Authorship Contributions: Surgical and Medical Practices - Ö.S., A.D.A., K.K., M.S.C..; Concept - Ö.S., A.D.A., M.S.Ç., K.B.; Design - Ö.S., A.D.A., K.B.; Data Collection or Processing - Ö.S., A.D.A., K.K., M.S.C.., A.O.K.; Analysis or Interpretation - Ö.S., K.B., A.O.K.; Literature Search - Ö.S., A.D.A., K.K.; Writing - Ö.S., K.K., K.B.

Conflict of Interest: No conflict of interest was declared by the authors.

Financial Disclosure: The authors declared that this study received no financial support.

\section{References}

1. Raudenska M, Balvan J, Fojtu M, Gumulec J, Masarik M. Unexpected therapeutic effects of cisplatin. Mettallomics 2019; 11: 1182-99.

2. Rybak LP, Mukherjea D, Ramkumar V. Mechanisms of Cisplatin-Induced Ototoxicity and Prevention. Hear Res 2019; 40: 197-204.

3. Cheki M, Ghasemi MS, Rezaei Rashnoudi A, Erfani Majd N. Metformin attenuates cisplatin-induced genotoxicity and apoptosis in rat bone marrow cells. Drug Chem Toxicol 2019: 1-8.

4. Ekborn A, Laurell G, Ehrsson H, Miller J. Intracochlear administration of thiourea protects against cisplatin-induced outer hair cell loss in the guinea pig. Hear Res 2003; 181: 109-15.

5. Mukherjea D, Rybak LP. Pharmacogenomics of cisplatin-induced ototoxicity. Pharmacogenomics 2011; 12: 1039-50.

6. DE Araujo JG, Serra LSM, Lauand L, Kuckelhaus SAS, Sampaio ALL. Protective Effect of Melatonin on Cisplatin-induced Ototoxicity in Rats. Anticancer Res 2019; 39: 2453-8.

7. Dayangan Sayan C, Tulmac OB, Karaca G, Ozkan ZS, Yalcin S, Devrim T, et al. Could erythropoietin reduce the ovarian damage of cisplatin in female rats? Gynecological endocrinology 2018; 34: 309-13.
8. Wallace WH, Shalet SM, Crowne EC, Morris-Jones PH, Gattamaneni HR, Price DA. Gonadal dysfunction due to cis-platinum. Medical and pediatric oncology 1989; 17: 409-13

9. Khan R, Khan AQ, Qamar W, Lateef A, Tahir M, Rehman MU, et al. Chrysin protects against cisplatin-induced colon. toxicity via amelioration of oxidative stress and apoptosis: probable role of p38MAPK and p53. Toxicol Appl Pharmacol 2012; 258: 315-29.

10. Vijayalakshmi B, Sesikeran B, Udaykumar P, Kalyanasundaram S, Raghunath M. Chronic low vitamin intake potentiates cisplatin-induced intestinal epithelial cell apoptosis in WNIN rats. World J Gastroenterol 2006; 12: 1078 85.

11. Longo V, Gervasi PG, Lubrano V. Cisplatin induced toxicity in rat tissues: the protective effect of Lisosan G. Food Chem Toxicol 2011; 49: 233-7.

12. Chtourou Y, Aouey B, Kebieche M, Fetoui H. Protective role of naringin against cisplatin induced oxidative stress, inflammatory response and apoptosis in rat striatum via suppressing ROS-mediated NF-kappaB and P53 signaling pathways. Chem Biol Interact 2015; 239: 76-86.

13. Kaygusuzoglu E, Caglayan C, Kandemir FM, Yildirim S, Kucukler S, Kilinc MA, et al. Zingerone ameliorates cisplatin-induced ovarian and uterine toxicity via suppression of sex hormone imbalances, oxidative stress, inflammation and apoptosis in female wistar rats. Biomed Pharmacother 2018; 102: 517-30.

14. Pytel D, Sliwinski T, Poplawski T, Ferriola D, Majsterek I. Tyrosine kinase blockers: new hope for successful cancer therapy. Anticancer Agents Med Chem 2009; 9: 66-76.

15. Steeghs N, Nortier JW, Gelderblom H. Small molecule tyrosine kinase inhibitors in the treatment of solid tumors: an update of recent developments. Ann Surg Oncol 2007; 14: 942-53.

16. Nilsson EE, Detzel C, Skinner MK. Platelet-derived growth factor modulates the primordial to primary follicle transition. Reproduction 2006; 131: 1007 15.

17. Merkwitz C, Lochhead P, Tsikolia N, Koch D, Sygnecka K, Sakurai M, et al. Expression of KIT in the ovary, and the role of somatic precursor cells. Progress in histochemistry and cytochemistry 2011; 46: 131-84.

18. Gonfloni S, Di Tella L, Caldarola S, Cannata SM, Klinger FG, Di Bartolomeo $\mathrm{C}$, et al. Inhibition of the C-Abl-TAp63 pathway protects mouse oocytes from chemotherapy-induced death. Nat Med 2009; 15: 1179-85.

19. Maiani E, Di Bartolomeo C, Klinger FG, Cannata SM, Bernardini S, Chateauvieux S, et al. Reply to: Cisplatin-induced primordial follicle oocyte killing and loss of fertility are not prevented by imatinib. Nat Med 2012; 18: 1172-4.

20. Kerr JB, Hutt KJ, Cook M, Speed TP, Strasser A, Findlay JK, et al. Cisplatininduced primordial follicle oocyte killing and loss of fertility are not prevented by imatinib. Nat Med 2012; 18: 1170-2.

21. Amin A, Abraham C, Hamza AA, Abdalla ZA, Al-Shamsi SB, Harethi SS, et al. A standardized extract of Ginkgo biloba neutralizes cisplatin-mediated reproductive toxicity in rats. Journal of biomedicine biotechnology 2012; 2012: 362049 .

22. Trompezinski S, Bonneville M, Pernet I, Denis A, Schmitt D, Viac J. Gingko biloba extract reduces VEGF and CXCL-8/IL-8 levels in keratinocytes with cumulative effect with epigallocatechin-3-gallate. Archives of dermatological research 2010; 302: 183-9.

23. Oliveira D, Latimer C, Parpot P, Gill CIR, Oliveira R. Antioxidant and antigenotoxic activities of Ginkgo biloba L. leaf extract are retained after in vitro gastrointestinal digestive conditions. Eur J Nutr 2020; 59: 465-76.

24. Chang L, Liu T, Chai Z, Jie S, Li Z, Liu M, et al. lincRNA-p21 Mediates the AntiCancer Effect of Ginkgo Biloba Extract EGb 761 by Stabilizing E-Cadherin Protein in Colon Cancer. Med Sci Monit 2018; 24: 9488-96.

25. Pandir D, Kara O, Kara M. Protective effect of bilberry (Vaccinium myrtillus L. on cisplatin induced ovarian damage in rat. Cytotechnology 2014; 66: 677-85. 
26. Yildirim N, Simsek D, Kose S, Yildirim AGS, Guven C, Yigitturk G, et al. The protective effect of Gingko biloba in a rat model of ovarian ischemia/ reperfusion injury: Improvement in histological and biochemical parameters. Adv Clin Exp Med 2018; 27: 591-7.

27. Celik O, Turkoz Y, Hascalik S, Hascalik M, Cigremis Y, Mizrak B, et al. The protective effect of caffeic acid phenethyl ester on ischemia-reperfusion injury in rat ovary. Eur J Obstet Gynecol Reprod Biol 2004; 117: 183-8.

28. Parlakgumus HA, Aka Bolat F, Bulgan Kilicdag E, Simsek E, Parlakgumus A. Atorvastatin for ovarian torsion: effects on follicle counts, AMH, and VEGF expression. Eur J Obstet Gynecol Reprod Biol 2014; 175: 186-90.

29. Livera G, Petre-Lazar B, Guerquin MJ, Trautmann E, Coffigny H, Habert R. p63 null mutation protects mouse oocytes from radio-induced apoptosis. Reproduction 2008; 135: 3-12

30. Gonfloni S. DNA damage stress response in germ cells: role of c-Abl and clinical implications. Oncogene 2010; 29: 6193-202.

31. Asadi-Azarbaijani B, Santos RR, Jahnukainen K, Braber S, van Duursen MBM, Toppari J, et al. Developmental effects of imatinib mesylate on follicle assembly and early activation of primordial follicle pool in postnatal rat ovary. Reprod Biol 2017; 17: 25-33.

32. Bildik G, Acılan C, Sahin GN, Karahuseyinoglu S, Oktem O. C-Abl is not actıvated in DNA damage-induced and Tap63-mediated oocyte apoptosıs in human ovary. Cell Death Dis 2018; 9: 943.

33. Chang Z, Wang HL, Du H. Protective effect of Ginkgo flavonoids, amifostine, and leuprorelin against platinum-induced ovarian impairment in rats. Genet Mol Res 2014; 13: 5276-84

34. Morgan S, Lopes F, Gourley C, Anderson RA, Spears N. Cisplatin and doxorubicin induce distinct mechanisms of ovarian follicle loss; imatinib provides selective protection only against cisplatin. PloS one 2013; 8: e70117.

35. Jiang W, Cong Q, Wang Y, Ye B, Xu C. Ginkgo May Sensitize Ovarian Cancer Cells to Cisplatin: Antiproliferative and Apoptosis-Inducing Effects of Ginkgolide B on Ovarian Cancer Cells. Integr Cancer Ther 2014; 13: Np10-7. 